THURSDAY, SEPTEMBER 3, I874

\section{FIFTH REPORT OF THE SCIENCE COMMISSION*}

II.

SO much has been written recently here and elsewhere on the origin and growth of the admirable Owens College, Manchester, that we shall not repeat the details on these points furnished by the Report of the Commission. Since it was opened in $185 \mathrm{I}$, it has held its way through many discouragements, and now, despite its comparatively narrow income, it is, at least from the point of view of scientific teaching and research, one of the most efficient institutions in the kingdom. Considering its comparatively recent origin and its provincial situation, the gifts bestowed upon it have been almost lavish; and yet the same complaint is made in the case of the Manchester College as is made by the two London institutions: the efficiency of the work of the College, and especially of its scientific side, is seriously crippled from want of adequate resources.

The whole endowments of the College, from its foundation till the present time, have amounted to $34,582 l$. In conncction with the recent movement for the erection of new buildings, inciuding various general and special endowments, an additional $168,300 l$. has been obtained; but even this is short by $60,200 \%$. of the sum required to carry out the proposed extensions. With the prospect of this deficiency the Governors of the College cannot at present undertake the establishment of any new chairs. If, however, they had adequate resources, it has been stated that they would probably proceed to divide the professorship of English and its History, and to found new chairs of Mixed Mathematics, of Applied Geology and Mining, of Astronomy and Meteorology, and of Architecture.

The total number of students in Owens College in 1 $\$ 73-4$ was 356 , being an increase of 19 on the previous year, and excluding 140 students belonging to the $\mathrm{Me}$ dical School.

The number of students entering the evening classes in $1872-3$ was 557 , which in 1874 . rose to the very large number of 889 .

With regard to the Owens College, the Commission makes the following recommendation :-

"Considering the strenuous and persevering efforts made by the great commercial community by which the Owens College is surrounded, and the cordial sympathy which these efforts have evoked, and which has manifested itself in the incorporation of other societies and schools with the College, and in the subscriptions and benefactions for special objects by which the exertions of the governing body have been seconded; we are of opinion that this institution has established a claim to aid from the national funds. We therefore recommend, in accordance with the views which we have expressed with regard to the two metropolitan colleges, that the Owens College should receive assistance from Government both in the form of a capital sum to be regarded as a contribution towards its building fund, and also in the form of an annual grant in aid of its working expenses, with the especial view of enabling it to complete the curriculum of studies by the establishment of new chairs."

$$
\text { * Continued from p. } 332 \text {. }
$$

The Newcastle College of Physical Science originated in a feeling on the part of the authorities of the University of Durham, that that University did not completely meet the educational wants of the North. To render the University more generally useful, it was thought that the best step that could be taken would be to establish a School of Physical Science in connection with it. Newcastle, as the site of this school, was preferred to Durham, in deference to the wishes of all the eminent local employers of labour.

The College was founded in 1871 for the teaching of physical science, particularly in its practical application to engineering, mining, manufactures, and agriculture. The funds necessary for its endowment were provided in part by the University of Durham, which gave, in the first instance, $1,000 l$. a year in perpetuity, which has since been increased; and, in part, by a subscription raised in the north of England.

From local sources, and by amalgamating with the College the other scientific institutions of Newcastle, Ix 7,000 . may be obtained.

The amount originally subscribed was of course insufficient to provide buildings for the new institution, and the College has at present to pay rent for the premises which it occupies. It is the opinion of the witnesses that it is extremely desirable that the College should be provided with buildings of its own. Sir William Armstrong says : "We consider the present accommodation as a makeshift, but without Government assistance it would be scarcely possible to undertake" to provide separate build ings appropriated solely to the College.

It was proposed, in the first instance, to provide four professorships, viz., of Pure and Applied Mathematics, of Chemistry, of Experimental Physics, and of Geology. To these professorships, lecturers have been added in literary subjects, in Greek and Latin, in English History and Literature, in French, and in German, besides a lectureship in Mechanical Drawing. It is thought very desirable by the founders of the College that other professorships of Science should be added to those already founded; indeed, a professorship of Biology has been recently established.

The number of students in $1873-4$ was 78 . The course of study is one of two years, there being two examinations, one at the end of each year; the candidates who pass the formal examination in Physical Science at the end of the second year to receive the title of Associate in Science of the University of Durham.

"There appears," the Report states, "to be every reason to think that the Newcastle College of Science is serving a most useful purpose in its own neighbourhood. There can be no doubt that local colleges in the great centres of manufacturing industry are in a position to meet local requirements which central institutions in London or the national universities are unable to do.

"According to Sir Wm. Armstrong the character of the instruction should be mainly, or almost entirely, of a purely scientific character, because at present there is no difficulty as regards practical knowledge, while on the other hand there is no means of acquiring scientific knowledge.

"The claims which the promoters of the College consider themselves to have upon the Government for assistance are founded upon the national usefulness of the institution, and on the amount of local support which it 
has received. Sir William Armstrong's view is that the promoters 'have a very sound claim upon the Government, considering how liberally the scheme has been supported locally. I think it would be a very fair thing if the Government, considering how much the nation benefits from the establishment of such colleges, in every case were to contribute a sum proportional to what has been raised in the locality towards the attainment of the obiect.' ....

"We concur to a considerable extent in the opinions expressed by these witnesses. The degree of success which has attended the College of Physical Science at Newcastle-upon-Tyne, both in the collection of local subscriptions and in the organisation of its system of instruction, leads us to express with confidence the hope that by further efforts of the same kind it will before long be placed in a position to establish its claim to assistance from the State."

With regard to the Catholic University of Ireland, while the Commission believes that it is calculated to do much good to the cause of scientific education, it cannot recommend Government to grant it any endowment.

"On a review of the evidence," the Report states, "we are satisfied that the establishment of the Scientific Faculty of the Catholic University has not been without advantage to the instruction of the Irish people, an advantage which might be considerably increased if this faculty could be more completely organised, and its professors increased in number and supplied with adequate means for practical teaching. And we have not failed to observe that at the present time fresh efforts are being made by the persons interested in this institution, to improve and to render more widely available the instruction afforded by it.

"It is also inclisputable that the Catholic University has received, and still continues to receive, a large amount of pecuniary support. The permanency, however, of this support, which proceeds, to a large extent at all events, from annnal subscriptions levied by clerical agency, cannot be predicted with any certainty.

"The peculiar organisation of this institution," the Report concludes, "the religious restrictions imposed upon the selection of scientific professors and lecturersrestrictions the removal of which it would be idle to anticipate; the incompleteness of a large portion of its arrangements for the teaching of science, and the uncertainty of its income, preclude us from recommending that it should receive a grant from public funds."

The general outcome, then, of the Fifth Report of the Science Commission is, that University and King's Colleges, London, and Owens College, Manchester, ought certainiy to receive assistance from Government, that the Newcastle College is in a fair way to prove that it deserves such assistance, and that it would not be advisable to subsidise the Catholic University of Ireland, as it is at present constituted.

J. S, K.

\section{THE APPLICATION OF THE LAWS OF SELECTION TO AGRICULTURE}

$\mathrm{T}$ every phase of life the law of selection comes into play. At one time it is natural, at another time it is more or less artificial. At every time, and in every place, we see evidence of the plastic character of the materials on which the vital principle operates.

In devoting my holidays to an agricultural tour in England this season, I have visited several seed-growers who are conferring great advantages on the public by careful selection of prent plants. I can speak on this point with the experience which a wide range of observation gives. I have myself, by selection, doubled the quantity of solid matter in turnips, and nearly doubled the number of seeds in ears of wheat.

If the principle of selection were universally applied with skill and care in the raising of our seed corn, what an enormous increase would thereby be made to the wealth of the agricultural classes of Great Britain and Ireland!

In our agricultural live stock a series of results, which are truly marvellous, have been accomplished by selection. And yet the principle is understood or practised only by a very small percentage of our farmers.

If any reader wishes to understand in a general way the change that has been made within the last quarter of a century, which is the measure of the life-time of the Royal Agricultural Society of England, let him take the Society's prize lists of 1839 and 1874 . In the interval, several new breeds of sheep and cattle have come to be recognised as having distinct types. Nature has had her share in the work. The soil and climate of every district impress certain characters and qualities on the animal; and, in his artificial selection, the farmer preserves these in whole or part. In studying, some years ago, the origin of the older breeds, I was much struck with the extent to which their distinctive characters were due to the natural conditions under which they rose. And in a recent inquiry into the history of the newly-established breeds, the same leading truth has become still plainer.

To give point to this short paper I derive an illustration from the influence exercised on the art of sheep-breeding by the remarkable change which, common observation tells us, has taken place in the material of garments in com. mon use. I refer to the well-known fact that tweeds and coarse cloths are now much more commonly used than in the last generation. Te meet the demand thus created the farmer has produced sheep which carry wool of longer staple than the old breeds.

My argument is well illustrated in the great plains in the west of Ireland, where the flock-owners have established a splendid new breed, called the Roscommon Sheep. In the production of this variety the breeder has of course exercised his skill in selection. He crossed Leicester tups of the very best English strains of blood with the native ewe ; and he repeated this over and over again until he obtained an animal of the type which suited him. Nature aided him in his art. It may be safely asserted that some of the peculiarities of the wool, as well as some of the peculiar conformations of the body, have been the work of Nature. And it is in retaining what was so well done by Nature that the highest skill is manifested. In England the best example of the argument is possibly afforded by the Lincoln breed of sheep, which stands so deservedly high in public estimation, affording as it does great weight of carcase with a remarkably heavy fleece of lustrous wool. Then, again, let us take the dark-shaded breeds-South Down, Shropshire Down, Oxford Down, and Hampshire Down. The South Down used to be more popular than it is now. It has been giving way in many places to an animal with a larger frame and with a fleece longer in the staple. The first that arose to displace it was the Shropshire, which has been followed by the Oxford Down. Each of these breeds 